\title{
Er det kaffe i himmelen?
}

\author{
Ved Kristin Ribe
}

\section{Jeg har skada meg selv i over tretten år. Jeg levde et veldig ensomt liv: Jeg trengte trøst. Jeg levde et veldig vilt liv: Jeg trengte hvile.}

Det var mye selvskading, det var alvorlig selvskading, det var å sy opptil tre ganger på samme dag. Det var å hoppe ut fra ambulanser i fart (fordi jeg skamma meg sånn over å være i den), det var mye politi, det var å komme på legevakt med buksa helt gjennomtrukket av blod, det var at en av vennene mine så meg med blodet silende ned og i følge med politi, det var intensivavdelinger på somatisk, det var å kutte seg på gata helt til noen tilkalte politiet og ambulanse. Det var ikke å kunne gå over broer uten å ha skikkelig vondt når jeg skulle prøve å motstå impulsen til å hoppe (og i Trondheim er det broer overalt), det var å være redd for å d $\varnothing$, men også være redd for å leve. Et vilt liv som ikke for meg var drama, og som av mine hjelpere ikke ble forstått som drama, men som et "dette her er vanskelig". Når skammen er for stor til å be om hjelp, når jeg i de første åra var avhengig av at noen andre syntes jeg burde få hjelp. Et vilt liv som helt opplagt kosta krefter. Et liv som jeg helt opplagt trengte å hvile meg fra innimellom. Jeg leste om selvskading. Jeg leste at de aller fleste "brenner ut" f $\varnothing$ r de er 35 år. Og jeg tenkte, herregud, da har jeg 11 år igjen.

\section{Et liv som ikke skal bli vanlig}

Å leve et sånt liv er ikke vanlig for menneskene rundt meg - det ble mer og mer vanlig for meg. Men jeg fikk mye hjelp. Jeg ble ofte innlagt. Det var mange som, ved det, indirekte sa: "Det er ikke sånn et liv skal være." Som sa, direkte: "Vi vil ta vare på deg." "Her kan du få hvile litt i trygge omgivelser. Vi er her." Og de kunne si til meg, når jeg ble skrevet ut: "Vi er her. Kom til oss når du trenger det."

\section{Kaffe}

Og så kan ikke pleierne og behandlerne på en akuttavdeling alltid være der. Noen ganger ryker og fyker det på en akuttavdeling. Men jeg trengte, mange ganger trengte jeg kontinuerlig trøst. Noen som var der sammen med meg. Men de kunne gi meg avtaler: "Det er travelt nå, men jeg skal komme til deg om en time."

Eller, de kunne si: "En innkomst først, og så er det deg." Og så måtte jeg stole på at de holdt avtalene. Og så kunne jeg, mens jeg venta, drikke kaffe. Det er ikke flust med ting å gjøre på en akuttavdeling, men jeg kunne drikke kaffe. Og det var etter hvert trøst i det, å holde i noe varmt. Og det var etter hvert trøst i det, å drikke noe varmt, la varmen kjennes nedover til magen. På den måten sitte der og holde ut det vonde, det ulidelig vonde, til miljøkontakten min kunne komme tilbake. Til jeg igjen kunne få den medmenneskelige omsorgen: Du ser veldig trist ut, er du det? Jeg drakk ikke av vane. Jeg drakk fra sykehuset. Kaffen ble noe som sykehuset ga meg. Det ble etter hvert en motvekt mot å føle seg forlatt. Trøsten fra de ansatte på sykehuset ble en motvekt mot $\mathrm{d} \varnothing \mathrm{d}$.

Jeg kunne sitte svært lenge med kaffen. Jeg kunne drikke litt og litt, holde ut litt og litt. Men mange ganger var jo kanna på avdelingen uvegerlig t $\varnothing \mathrm{mt}$, drukket opp. En så stor nedtur at jeg svært ofte fylte to kopper om gangen og gjemte den ene. Så jeg alltid skulle ha muligheten. Og det var ikke som å gjemme barberblader for å ha mulighet. Å gjemme kaffe var en helt annen tilsnikelse, det var å snike til seg gode opplevelser. Et vanvittig sprang.

Jeg kunne sitte der, nesten bevegelsesløs, men likevel ha noe å gjøre. Røre litt på koppen, drikke litt, vente. Røre litt på koppen, skifte grep. Noe som ikke var dødens ubevegelighet. Ikke sitte og bli vant til $d \varnothing$ dens ur $\varnothing$ rlighet. Jeg var sliten forbi alle skalaer, og det jeg $\varnothing$ nsket framfor noe var hvile. Sitte og stirre på hengebjørka utenfor. Og så var det med kaffen likevel ikke kun stirring.

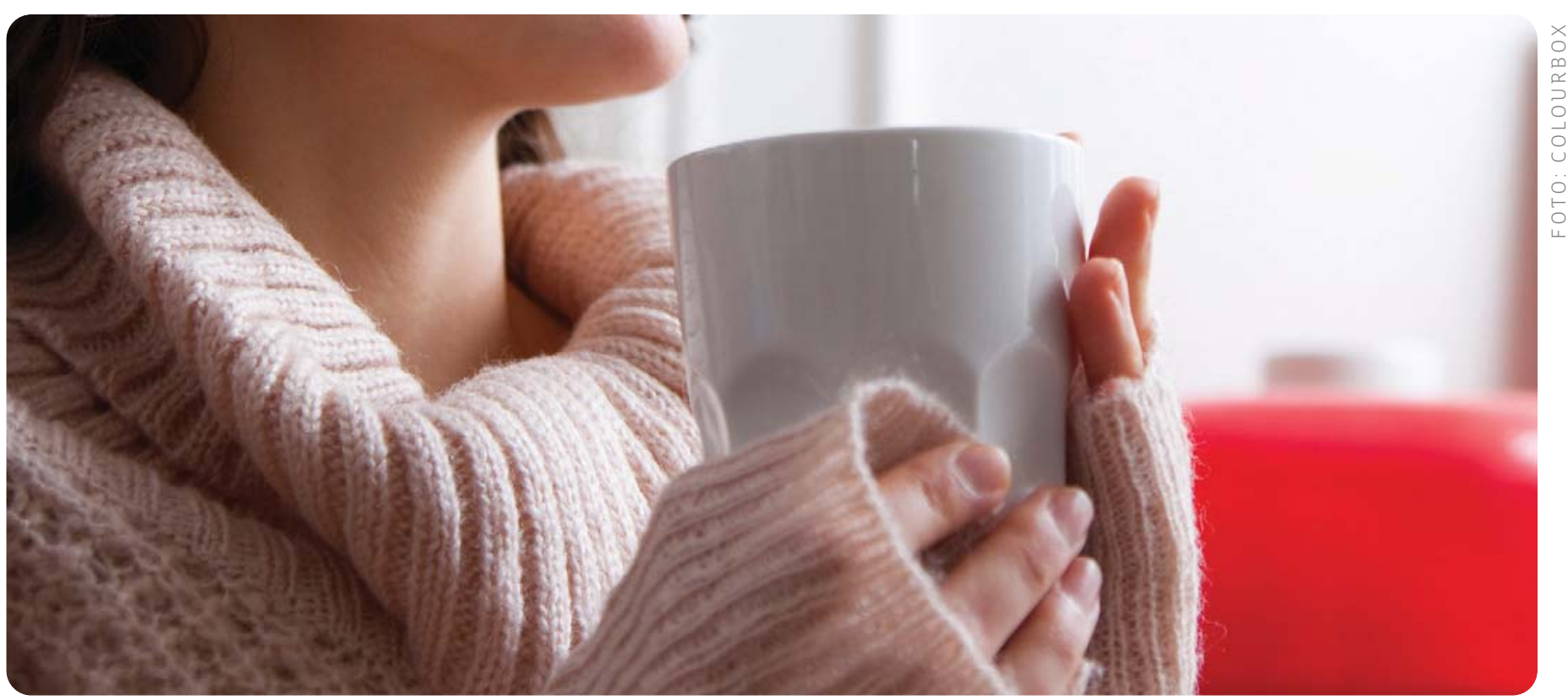




\section{Og jeg tror på en himmel}

Så ble det mange ganger likevel for vondt. Jeg ville d $\varnothing$, jeg kjente i hele meg: "Dette orker jeg ikke. Jeg har prøvd og prøvd å gi livet en sjanse, men dette vonde går ikke over. Jeg må slutte å lure meg selv til å tro at det kan gå over.” Og jeg tror på en himmel. Der jeg kan få uendelig omsorg, uendelig mye trøst. Og jeg trengte trøst, i hele meg trengte jeg trøst. Og så kunne jeg likevel bli bekymra: Er det trøst i himmelen? Er det sikkert at det finnes et sånt sted? Og jeg spurte kontakten min, redd, omforma: "Er det kaffe i himmelen?" Og hun svarte bare, uten å tenke seg om: "Nei."

\section{Evnen til å roe seg selv ned}

Beroligende medisiner blir gjerne tilbudt de som skader seg selv. Og bidrar vel dessverre, som alkohol, til å forstørre og intensivere de følelsene som allerede finnes. Samtidig som de - farlig - tar bort det indre forsvaret mot å gjøre seg selv noe vondt. Og ja, jeg har opplevd sånne virkninger. Men jeg tenker også på beroligende medisiner i forhold til å lære seg å roe seg selv ned. Gjennom å sitte på en avdeling med kaffe, klarte jeg mange ganger å holde ut uten å kutte, både fordi de sa de $\varnothing$ nsket at jeg skulle klare det og viste de virkelig ville meg vel, men også fordi jeg selv ikke var passiv. Og så kan det sies at koffein også er et stimulus, at det også er noe jeg tilfører systemet, men da synes det jo rart, det jeg hevder, at kaffe ga meg ro. Og så er det ikke rart. At det symbolske som kaffen representerte var langt viktigere enn det kjemiske.

\section{At ikke alt trenger å være vanskelig}

Jeg har her presentert det som vel er et ganske privat forhold til kaffe. Som ikke på noe vis er allmenngyldig. Og så kan dette likevel være et eksempel på at tilsynelatende uvesentligheter, som å sette fram kaffe på en avdeling, kan ha helt essensielle funksjoner. At ikke alt trenger å være så vanskelig, i jobbing med selvskadere og suicidale. Dette er et eksempel på at mye i behandling ikke har entydige virkninger. Vi kan tenke at kaffen hjelper i forhold til kaffe-tørst. Men for meg ble tilbudet en kaffe-trøst. Kaffe kunne gi meg at jeg lettere holdt ut til hjelperne mine igjen kunne være tilstede.

Men kaffe kunne også gi meg et eksempel på fine ting som livet har å by på. At det ikke bare var kaffe, men alltid "något attåt". Kaffe er et eksempel på "et vanlig liv", der ikke selvskading og selvmordstanker behøver å være så framtredende.

\section{Sekundærgevinst}

Jeg har trengt et trygt sted, der jeg kan få hvile litt. Jeg har trengt et trygt sted, der kuttetrangen kan få avledning.
Der jeg sammen med andre mennesker kan få trøst. Ikke blodets trøst, men samtalens trøst. Der jeg kan få tilbake krefter til også å tenke på livet. Og så skjedde det, det utrolige framskrittet, at det gikk an å ta med kaffen "ut" etter en innleggelse. Det gikk etter hvert mer og mer an å drikke kaffe også hjemme, og tenke: "De finnes. Sykehuset og de som jobber der, som vil at jeg skal ha det bra, de finnes.” Jeg ble av en ekstravakt kalt "kaffetorpedoen". Hvilket jeg stolt ser på som en hedersbenevning.

Jeg er mye rundt og holder foredrag. Og jeg nevner dette, det at kontakten min sa at det ikke er kaffe i himmelen. Og så ble jeg så utrolig glad her forleden, da en av tilhørerne kom bort til meg etterpå og sa: "Jeg ville så gjerne gi deg kaffe." Hun forsto.

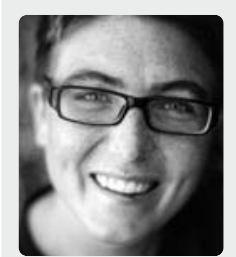

Kristin Ribe (f. 1972) har hovedfag i nordisk litteratur. Hun utga i 2007, basert på egne opplevelser fra over 13 år med alvorlig selvskading, fagboka Selvskadingens dynamikk (Universitetsforlaget) sammen med psykolog og stipendiat Anita Moe. Hun har også utgitt romanene Forsnakkelser (2003), Drikke det vannet som ormene hadde ligget $i$ (2006), VÅKE (Håret gråter jeg i) (2008), Syn (2010) og Natt, regn (2012), alle ved forlaget Oktober.

www.kristinribe.no kristin_ribe@hotmail.com

Foto forfatter: Siri Ursin

\section{Olafs minnepris 2012 til Reidun Kjelling Nybø}

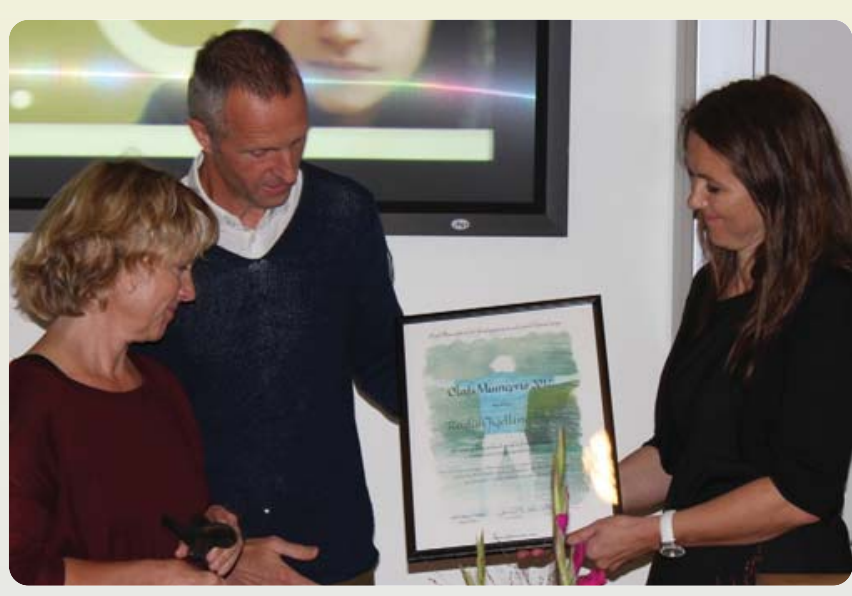

Stiftere av Olafs Minnefond, Mette Marie Tangen og Jon Schultz, deler ut Olafs Minnepris 2012 til Reidun Kjelling Nyb $\varnothing$.
Mandag 10. september 2012 ble Olafs Minnepris delt ut for andre gang. Årets vinner ble journalist og redakt $\varnothing \mathrm{r}$ Reidun Kjelling Nybø som har jobbet spesielt for åpenhet om temaet selvmord, og slik gjort en innsats for å forbedre kvaliteten i omtale av selvmord i massemediene.

Olafs minnepris deles ut av Olafs Minnefond for forebygging av selvmord blant unge. Prisen ble utdelt under den lokale markeringen av Verdensdagen for selvmordsforebygging i Akershus, arrangert av LEVE og HIOA. Olafs Minnefond er opprettet av Olafs foreldre og søsken etter at Olaf tok sitt eget liv 19 år gammel.

Prisen er en anerkjennelse til personer som har bidratt i arbeidet med å forebygge selvmord blant unge i Norge.

http://www.olafsminne.org/ 